\title{
Self-perceived factors associated with smoking cessation among primary health care nurses: a qualitative study
}

\author{
Miguel Bennasar Veny ${ }^{1}$ \\ Jordi Pericas Beltrán² \\ Susana González Torrente ${ }^{3}$ \\ Priscila Segui González ${ }^{4}$ \\ Antoni Aguiló Pons ${ }^{5}$ \\ Pedro Tauler Riera ${ }^{6}$
}

\begin{abstract}
The aim of this work was to characterize the views of nurses about factors modulating smoking cessation. Results of this study will allow us to design helping interventions with the maximum specificity for nurses. A qualitative study through a semi-structured interview of 15 Primary Health Care nurses who were smokers was performed. In contrast with other studies in which nurses were not aware of any particular social pressure to give up smoking, 18 months after the application of the Anti-Smoking Spanish Law, this feeling was expressed. Therefore, the main reasons for giving up smoking include that smoking in public is every day worse seen, together with a sense of shame and guilt in front of their social and family environment, especially for being a professional group dedicated to health.
\end{abstract}

Descriptors: Smoking Cessation; Nursing; Primary Health Care; Cognitive Dissonance; Women's Health; Qualitative Research.

\footnotetext{
${ }^{1}$ RN, M.Sc. in Anthropology, Departamento de Enfermería y Fisioterapia, Universitat de les Illes Balears, Spain. E-mail: miquel.bennasar@uib.es. ${ }^{2}$ RN, Ph.D. in Science, Departamento de Enfermería y Fisioterapia, Universitat de les Illes Balears, Spain. E-mail: jordi.pericas@uib.es. ${ }^{3}$ RN, M.Sc. in Primary Health Care, Servicio Balear de Salud, Spain. E-mail: sgonzalezt@ibsalut.caib.es.

${ }^{4}$ Sociologist, M.Sc. in Sociology, Departamento de Enfermería y Fisioterapia, Universitat de les Illes Balears, Spain. E-mail: priscila.segui@gmail.com.

${ }^{5}$ Physician, Ph.D. in Medicine, Departamento de Enfermería y Fisioterapia, Universitat de les Illes Balears, Spain. E-mail: aaguilo@uib.es. ${ }^{6}$ Biochemist, Ph.D. in Biochemistry, Departamento de Enfermería y Fisioterapia, Universitat de les Illes Balears, Spain. E-mail: pedro.tauler@uib.es.
}

Corresponding Author:

Miguel Bennasar Veny

Universitat de les Illes Balears

Edificio Guillem Cifre de Colonya

Cra. de Valldemossa km 7,5, 07122

Palma España

E-mail: miquel.bennasar@uib.es 


\section{Tabagismo em enfermeiras de cuidados primários à saúde: um estudo qualitativo}

O objetivo deste estudo foi identificar os fatores percebidos por enfermeiras fumantes como facilitadores ao abandono do tabagismo, com o propósito de, posteriormente, elaborar intervenções de ajuda com maior especificidade para esse grupo. Foi realizado estudo qualitativo, por meio de entrevistas semiestruturadas, com 15 enfermeiras de cuidados primários à saúde, que eram fumantes. Ao contrário de outros estudos, os quais as enfermeiras não percebiam pressão social para deixar o hábito tabágico, 18 meses após a vigência da Lei de Prevenção ao Tabagismo, as enfermeiras entrevistadas expressaram sentir pressão social. Portanto, entre os principais motivos para abandonar o hábito tabágico é que, a cada dia, fumar em público é malvisto, e está aliado a sentimentos de vergonha e culpa no seu entorno social e familiar, principalmente por se tratar de um grupo profissional dedicado aos cuidados da saúde.

Descritores: Abandono do Hábito de Fumar; Enfermagem; Atenção Primária à Saúde; Dissonância Cognitiva; Saúde da Mulher; Pesquisa Qualitativa.

\section{Tabaquismo en enfermeras de Atención Primaria: un estudio cualitativo}

El objetivo de este trabajo fue identificar los factores percibidos por las enfermeras fumadoras como moduladores del cese tabáquico, con el fin de diseñar posteriormente intervenciones de ayuda con la máxima especificidad para este colectivo. Se realizó un estudio cualitativo mediante entrevista semiestructurada a 15 enfermeras fumadoras de Atención Primaria de Salud. Contrariamente a otros estudios en los que las enfermeras no percibían una especial presión social para dejar el hábito tabáquico, 18 meses después de vigencia de la Ley de Prevención del Tabaquismo sí que la expresan. Por ello, entre los principales motivos de cese figura el que cada día esté peor considerado fumar en público, unido a un sentimiento de vergüenza y de culpa ante su entorno social y familiar, especialmente por tratarse de un colectivo profesional dedicado a los cuidados de salud.

Descriptores: Cese del Tabaquismo; Enfermería; Atención Primaria de Salud; Disonancia Cognitiva; Salud de la Mujer; Investigación Cualitativa.

\section{Introduction}

According to the 2006 National Health Survey, smoking prevalence in Spain was $29.5 \%$ (35.3\% in males and $23.9 \%$ in females) and very similar in the Balearic Islands. These percentages used to be much higher: for nurses between 35 and 40 years old working for the National Health Institute, smoking prevalence was $45 \%$ in 1998 and $47 \%$ in Madrid in 2001. However, in 2006, among nurses in the Balearic Islands, smoking prevalence was only $26.7 \%, 25.0 \%$ among female nurses and $33.7 \%$ among male nurses(1). Regarding smoking prevalence, the current trend is downward in men and stable or even upward in women.
One of the main roles of nurses is to educate smokers in the prevention of unhealthy habits and diseases. This aim can be achieved through professional advice regarding unhealthy practices (such as smoking), by helping individuals and the population to modify such behavior and, also, through professionals' own lifestyle, playing a role as models for the rest of the population ${ }^{(1-2)}$.

As far as smoking is concerned, nurses have been carrying out this role by promoting health education, including advice on smoking cessation, both individually and in groups, and have proved their competence and ability concerning these issues. In fact, in Spain, 
around $50-70 \%$ of nurses think that they have to play the role as healthy social models in all health issues related to smoking (prevention, cessation, etc.). Furthermore, around $90 \%$ of the general population feel that handling and helping people to give up smoking is the responsibility of nurses ${ }^{(3)}$. Thus, nurses can play an important role in the prevention of smoking by promoting health education. However, the nurse's role in the prevention of smoking or in helping people to give up smoking is often compromised because the smoking prevalence among nurses is very similar to that in the general population.

In our environment, only a few qualitative studies have been carried out to assess the opinion of nurses who smoke with regards to giving up smoking. The aim of this work was to characterize the views of nurses on factors modulating smoking cessation. As a long-term aim, the results of this study will allow us to design helping interventions with the maximum specificity for nurses.

\section{Methods}

In the present study, a qualitative methodology was used, based on the phenomenological perspective, from the perspective of the informers, in order to reconstruct the ways Primary Health Care (PHC) nurses feel, think and act, to outline the determining factors that influence smoking cessation, in the assumption that the interesting reality is the one nurses themselves see as important.

This approach allowed us to investigate how, according to other members of society, nurses who smoke must live with their own conscience and relate the acts that are inconsistent with their social construct and life-world; that is, the social construction of a nurse is not identified with the life-world as a smoker, so that a nurse's individual smoking is in contradiction with the inter-subjective reality created by society. Schultz suggested the term world of life in $1932^{(4)}$. This author never conceives the subject alone, but always in a social relation, characterized by actions and intentions. Schultz described how, in an inter-subjective world, where people at the same time create the actual society and are subject to constraints they exert on the social and cultural structures their predecessors created. Thus, nurses who smoke signify the experience, so that its meaning, in contradiction with the world of life that surrounds the latter, is what determines what is perceived as bad and what is perceived as good or positive. So, nurses who smoke are in contradiction because the world of life is inconsistent with their subjective reality ${ }^{(4-5)}$.

Through this study, we aimed to establish the factors inducing nurses to give up smoking, looking for the ethical, subjective factors nurses perceive as either positive or negative to encourage smoking cessation ${ }^{(5)}$. Therefore, we decided to conduct a qualitative study because we were interested in carrying out a detailed analysis of the words nurses use to explain their points of view: a member of the research group carried out in-depth semi-structured interviews with PHC nurses who were smokers. Basically, the interview consisted of exploring the main factors encouraging nurses to give up smoking.

The inclusion criteria were: female nurses, who had been habitual smokers for at least two years prior to the study, working at a Primary Health Care Centre (PHCC) for at least a year and consenting to participate in the study.

Regarding recruitment of participants, first of all, a brochure was devised, explaining that the researchers were looking for staff to participate in the study. However, this method was absolutely unsuccessful. Thus, with institutional permission, we approached each unit supervisor to get the chance of contacting nurses.

In the Balearic Islands, there are 36 PHCC. In total, 24 supervisors from all health centers were asked for information about the number of nurses who met the inclusion criteria, obtaining a population of 34 nurses. After informing these nurses about the aim of the study and inviting them to participate, 28 accepted. Finally, from these 28 nurses, 20 participants were selected on the basis of population representation criteria. Among the study participants, $60 \%$ belonged to urban health centers and $40 \%$ to rural centers. An appointment was made for the interview and - during the interview - the nurse was again informed about the aim of the study. Furthermore, any doubts were resolved and the informed consent form was signed so as to guarantee the voluntary nature, confidentiality and autonomy when it came to making decisions.

From April to June 2007, interviews were performed at the PHCC, a place the interviewee knew well, as we thought this would contribute to more natural answers. A recorder was used to permit posterior analysis of answers. The interviews were conducted individually over a period of several days without the presence of others, and were semi-structured so that subjects could add any item of interest in order to make them more interactive and participatory. 
Approval for the current interview study was obtained from the Research Ethics Committee of the University of the Balearic Islands and all study participants were assigned fictitious names to guarantee anonymity.

As the data was collected, it was analyzed and came to saturation when 15 interviews had been carried out. Three researchers compared the data and codified, categorized and shared the results until reaching a complete consensus. The computer application Atlas-Ti for qualitative analysis was used.

For a complete analysis of the discourse texts, an analysis based on hermeneutic interpretation was carried out, dividing the texts into meaning units, including different categories, reflecting the actions the nurses perform in relation to smoking and how they are influenced by the surrounding life-world and by their own conscience ${ }^{(4-5)}$. Furthermore, subcategories were created to permit a more detailed analysis. These categories and subcategories meant they were directly related to the research question established at the beginning of the study. Furthermore, the meaning categories were analyzed as objectively as possible to prevent the introduction of concepts related to our own subjective reality.

The study presents some limitations that need to be acknowledged and addressed: 1) As previously indicated, some problems were found when recruiting participants, to the extent that we had to change the method of obtaining information from a focus group method to a personal interview; 2) Participation of nurses was voluntary. Therefore, a bias could be produced in the selection of participants and, hence, in opinions regarding the smoking habit; 3 ) The mean age (45.8 years) of the study group was higher than the mean age of nurses from the Balearic Islands (38.1 years); 4) Only smoker nurses were considered for participating in the study. Ex-smoker nurses were not considered to take part in the study. This last group could have different thoughts; 5) Taking into account that some researchers were nurses, there could be a bias that Bourdieu called the "illusion of transparency", which may bring about a hurried understanding of the reality and which, above all, may be conditioned by their own subjective projection. On the other hand, and with all due caution, we believe that health interventions should be based on the concept of health of our own community and, besides, we feel a commitment to the problems of patients and the professionals who take care of them, in this case $\mathrm{PHC}$ nurses ${ }^{(6)}$.

\section{Results}

The participants' mean (SEM) age was $45.8 \pm 9.6$ years, with a mean of $22.4 \pm 8.7$ years working as nurses (14.1 \pm 5.7 years in PHC). Among participants, $73.3 \%$ were married and $26.6 \%$ separated or divorced; $20 \%$ had no children, $40 \%$ had one and $40 \%$ two.

The mean age of taking up smoking was $18.9 \pm 3.0$ years, and participants smoked $16.7 \pm 11.5$ cigarettes/ day; with $41.9 \pm 22.3$ minutes between the moment they got up and their first cigarette. As far as the phase of change in the smoking habit is concerned, $27 \%$ were pre-thinking about it, $47 \%$ thinking about it and $4 \%$ in action. Furthermore, $80 \%$ had tried to give up smoking and $20 \%$ had not.

The content of the interviews was grouped into categories according to thematic similarity:

\section{Willingness to give up smoking}

Almost all interviewees were thinking about giving up smoking sooner or later. They considered it inappropriate to reach an elderly age and still be smoking: I'm thinking about giving up smoking. The thing is I'm close to fifty and I don't want to be an old person who smokes, do I? (E15)

One of the bases for success in giving up on which most participants coincided was that the efficacy of any method for giving up smoking depends on the firm decision of wanting to give up. Furthermore, and regarding group therapies, group homogeneity seemed to be a factor helping group therapies. They feel that, when belonging to a similar social, cultural or work level or environment, they had the feeling that they shared something more than the habit. Regarding the question of a firm decision: To give up smoking, you have to want to. In other words, you have to be ready. No method works until you really want to give it up... (E7)

As far as attempts to give up smoking are concerned, almost all study participants reported that they had tried to give up at some time in their life. They attributed their failure or success to materialistic factors, such as having paid or not: I went once to a session to give up smoking offered by a laboratory. It didn't work because I didn't trust it, it was like group hypnosis and I was afraid of looking ridiculous. I have never tried again. Perhaps if I had paid for it? (E2)

Implicitly or explicitly, almost all interviewees stated their intention of giving up the smoking habit and their incapacity to give up in spite of using the most habitual strategies (even pharmacological ones): I tried two years ago. I bought the whole treatment, the patches... Well, 
I spent two hundred euros. I bought the whole treatment. I said, well here I go. At eight o'clock in the morning. Already desperate because I couldn't smoke my morning cigarette, I put on the patch... eleven in the morning I went out into the patio, and out into the street and I smoked a cigarette. I took off the patch and I said look, leave it (laughs). (E13)

\section{Reasons for giving up smoking}

Health and, more frequently, fear of health deterioration were common reasons for giving up smoking, even more important than loss of beauty. However, most participants in the study recognized that this fear was "not enough" for giving up smoking, and they would not give it up until the health problem was clearly manifested. Regarding this health problems, one deep-rooted motivation found in our study was the fear of cancer - commonly lung cancer - induced by smoking: I'm a disaster but well... I suppose one day I'll get a shock and then I'll say, Ah! I must give it up. But it'll have to be a real shock. Yes, we're like this... Because what... actually concerns me, is cancer, of course, as is natural and... of course, phew! When you get it (laughter) now you've blown it... (E13)

Most interviewees gave up smoking or significantly decreased their consumption when they became pregnant. They described that they did not smoke because they did not want to harm anyone (the child) and that, once they had had the child, or had finished breast-feeding, if that was the case, they could take up smoking again because they were only hurting themselves. Among the ones who did not have any children, one of the hypothetical situations in which they would give up smoking would be if they were to get pregnant: During pregnancy I did not smoke. But afterwards, I was no longer hurting anyone, you see? You hurt yourself. Pregnancy is such a strong motive that it blocks you totally. While you are pregnant, no need, nothing. I should be pregnant all my life, and then I wouldn't smoke (laughter). (E9)

On the other hand, the pressure of children when they are a little older, in some cases even paying for therapies for their mother to give up smoking, also enhanced cessation, although it was conditioned to them not needing too much effort to give it up: At home, my children call me all sorts, everything they can... I don't pay attention to them, I go somewhere else and I smoke a cigarette, on the balcony, in the kitchen, wherever. With them by my side I don't smoke, because it's a closed space and the girls needn't inhale my smoke when there are other places where I can smoke without disturbing anyone. I know I disturb when I smoke. (E8)

\section{Health related professionals as a healthy model}

The interviewees thought that smoking in public is frowned upon lately and has worse connotations if the smoker is a nurse. For some of them, this was actually their personal viewpoint and they also considered that it was even worse if they smoked while wearing their white coat, which identifies them as health professionals: We were brought up when smoking was the thing done and now it's frowned upon... In other words, now I smoke and I hide. In any hospital, you can see people outside in uniform smoking and this causes a slightly uncomfortable sensation. I would be incapable of going out with my white coat and smoking a cigarette and for my patients who know me to see me at the door of the center smoking a cigarette. No, no. (E14)

The shame or incongruence between the advice about not to smoke health professionals (physicians or nurses) give to patients and their condition of being smokers (which they sometimes showed) was considered a factor for giving up tobacco, as they frequently think they are a model of conduct in terms of health for patients: Because, as I tell you, I think you should not smoke in the workplace, first because now it's banned, but even before that, I avoided smoking at work. I can't advise someone to do as I say, not only smoking, I can't be really fat and tell the patients they need to lose weight. (E4)

\section{Contradictions, excuses and self-justifications}

Most participants in the study did not feel discriminated by their colleagues and, even though they did feel like that at first, the others ended up getting tired of criticizing them.

Furthermore, they did try not to smoke in the workplace. Other participants, however, did feel discriminated, and considered they already knew smoking is harmful and that they should give it up. Nevertheless, they respected the surroundings of the rest by smoking separately and felt the fact that they were constantly being reprimanded about it an intrusion in their private life. They did not feel that this helped them give up the habit, at times quite the opposite, and they even felt "criminalized": Yes, I find it a pain and unpleasant and I sometimes answer back. That they poke their noses into such an intimate, personal thing...if only I could give up smoking just because someone tells me to give it up, but it doesn't work like that... Tobacco has been criminalized a lot, only today I myself have treated a drug addict and they make you feel sorry for them, but with tobacco you're treated like a criminal. (E3) 
Some people explained their experiences about relapses without finding any cause that could justify the "return" to tobacco: I have experience as a patient you know? That I would never go back to it... in other words, if I gave up smoking, as I gave up smoking a few years ago, I wouldn't even pick up a fag end, come on, not even as a joke. (E14)

They said they enjoyed the general recognition when they managed to go for a time without smoking. Yet, on relapsing, they felt ashamed in front of others, perhaps more so because of them being nurses: I did the course, I really liked it, I gave up smoking on that course, I was applauded... they wouldn't be applauding me now... I smoke a little more now than I used to, I feel guilty. Now, I've been feeling quite guilty for over a year when I smoke. (E6)

\section{Discussion}

The willingness to give up smoking, the attempts to give up, as well as the expression of a desire to give up smoking without being able to, are frequent and common in most of the studies carried out among smoking nurses. These observations serve to confirm the addictive power of tobacco(7).

About the reasons for giving up smoking, as far as giving up smoking is concerned, the fear of deteriorating health (especially the fear of cancer), seems to be the main reason for the desire to give up ${ }^{(8)}$. However, as shown in the present study, this fear is not always strong enough for the smoker to give up smoking. The presence of tobacco related illnesses in other people is also a reason for giving up, but only under certain

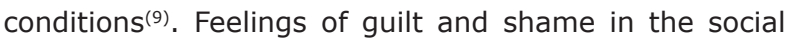
and family environment, as they should know the problems of smoking better than anyone and should not smoke, also appear in other studies ${ }^{(7)}$. Our respondents think that nurses (and the population as a whole) know everything about the harmful nature of tobacco, yet little concerning the biochemical mechanisms of this action, withdrawal symptoms or a combination of strategies in order to give up, imagining, therefore, that this knowledge - and, consequently, demands - is mostly inexistent ${ }^{(10-11)}$.

In contrast to other studies showing that nurses did not perceive any particular social pressure to give up the habit (USA-California), guilt and shame appear in most studies and seem to be a consequence of cognitive dissonance which, even though it may be a source of suffering, may be able to provide enough energy or motivation, so that the individual will think about giving up the habit. Thus, in general, PHC nurses consider the pressure family and friends or other professionals exert as a factor that encourages them to give up, which is in agreement with other authors ${ }^{(12)}$.

Most of the interviewees consider having tried to give up smoking more than once as a positive predisposing factor for giving up, since they usually express it as a positive experience and indicate that they felt much better when they did not smoke. However, in most studies, it does not appear as a factor underlying giving up, and may even be related to failure ${ }^{(13-14)}$.

Most of the nurses who took part in the present study considered tobacco incompatible with pregnancy, even during the period before "trying for" one. This fear of harming not only the fetus, but also children and other members of their family has been widely observed(15). Giving up the smoking habit during pregnancy has already been described in many papers, reaching approximate percentages of $20-25 \%$, although around $75 \%$ of mothers take up smoking again six months after giving birth(16-17).

In contrast to many others, the nurses who took part in the present study did not indicate any economic reason as essential for giving up ${ }^{(12,18)}$. This seems to confirm that Spain is one of the developed countries with the cheapest price for tobacco(19).

Regarding the self-consideration as professionals playing a role as healthy models, and in agreement with previous studies, we found that PHC nurses consider themselves as a healthy model. Furthermore, both in the present study and in previous ones, almost all nursing participants think that health professionals should never smoke in front of patients ${ }^{(20)}$. However, when nurses smoke, the feeling of being a model towards patients decreases, as does the promotion of smoking cessation (7,21-22).

The smell tobacco smoke leaves is a frequent motive of complaint for people around the smoker (e.g. children, husband, and colleagues) and also for the smoking nurse herself. In fact, the smoking nurse may end up adopting different ways to reduce the smell of smoke (perfumes, continuous washing, frequent clothes changes and strong-smelling sweets) so patients or workmates do not notice that she smokes, and this could even be a factor favoring giving up ${ }^{(23)}$. In pregnant women, a high degree of intolerance to the smell of tobacco has been described, helping them give up smoking. Unfortunately, this effect disappears after giving birth. Preventing children from breathing in tobacco smoke is, also, a reason for giving up smoking, or at least to refuse to smoke in shared rooms ${ }^{(12)}$. 
The Anti-Smoking Law has been in force in Spain since 2006. This ban of smoking in the workplace, together with the growing number of people giving up the habit as a consequence of this law, are reasons nurses indicate for giving up, in accordance with other studies ${ }^{(1)}$.

The smoking habit is sometimes the reason for arguments between smokers and non-smokers sharing the same areas. On occasions, this leaves the smoker feeling harassed, especially if the others do not smoke. Nevertheless, in the specific case of our respondents, they believe that one of the main reasons for them not being discriminated against is because most of them have stopped smoking in the workplace. This fact leads us to think that there is still a certain amount of conflict as to what smokers and non-smokers understand as consideration or lack of consideration when they share spaces. As described in the literature, in general, the assertive power of non-smokers to smokers is very weak $^{(24)}$.

Most of the smoking nurses feel (like patients) isolated and neglected by their colleagues and, above all, by the institutions where they work ${ }^{(25)}$. They think some specific support from their own class - health and nursing - would be very helpful in order to give up the smoking habit. The message to give up should be issued in nursing journals and in the workplace, combining the characteristics of being positive and comprehensive with the great difficulty involved in giving up smoking and, also, preventing guilt(10).

It is widely demonstrated that nurses are one of the ideal professional groups to help giving up smoking and that their interventions are as efficient, or even more, as those of other professionals. However, nurses have some specific limitations in this work. Furthermore, nurses, as a group mainly composed by women, present another important limitation because it has been observed that give up smoking is more difficult for women than for men. Among the most significant obstacles, the following should be highlighted:

The absence of governments' firm anti-smoking policies $^{(24)}$. These policies could be focused on different aspects, such as: a) Training in different strategies for giving up smoking and the recognition of this training; b) Incentives for giving up smoking; c) Promoting skills about how to handle stress induced by common workrelated factors in the health sector; d) Ensuring less stressful work conditions (adequate staff, promoting self efficiency, the adaptation of procedural guidelines, clarifying scopes of authority, shifts, etc.).
A cognitive dissonance could be produced in nurses when they smoke (behavior) and they know, as health professionals, that smoking produces harmful effects (cognition). This, in turn, could have broad-ranging repercussions on patients because nurses' credibility is reduced in a relationship in which nurses' behavior is in contradiction with their own advice.

\section{Conclusion}

From the opinions collected through our interviews, we can conclude that, as with the general population, nearly all the nurses say they are sorry they ever took up smoking, and over three quarters declare their desire to give it up and not being able to do so.

The most widespread reason in support of giving up smoking is the fear of deteriorating health, especially the fear of cancer. Another of the main motives for giving up is that smoking in public is increasingly frowned upon, together with a feeling of shame and guilt in their social and family environment, as well as the perception of being a health model for the rest of society. In fact, most participants say they have given up smoking in the workplace and even hide their habit from colleagues or clients outside the workplace. The ban on smoking in the workplace since 2006 and the fact that many colleagues have given up smoking are also seen as reasons for giving up.

Unlike most of the studies carried out in other countries in which the economic cost of tobacco occupies one of the top places as a motive for giving up, in our study, it does not appear in any of the interviews.

Clear anti-smoking policies affecting all staff including the highest posts, should be implemented in health institutions: banning smoking both in closed spaces and in the surrounding areas, particularly when working with the public. At the same time, support measures should be offered to those members who decide to give up smoking.

We consider additional research should be conducted to explore certain issues related to our findings. An assessment of the association between the level of training with regard to smoking and smoking behavior should be conducted. Furthermore, an assessment of the attitudes to smoking and governing smoking, including the effects of the Spanish act and its behavior in this respect. Finally, the importance of the effect of family involvement in starting, keeping up and giving up smoking should also be analyzed. 


\section{Acknowledgements}

The present study received a grant from the Government of Spain to carry out research into the assessment of health technologies concerning research in health services, within the framework of Plan I+D+I.

\section{References}

1. Pericas J, Ayensa JA, Milán J, Contreras P, Serra F, Sureda AM. El hábito tabáquico en el colectivo de colegiados en enfermería de la Comunidad de las Islas Baleares. Index Enferm. 2007;58:26-30.

2. Svavarsdóttir $\mathrm{MH}$, Hallgrímsdóttir G. Participation of Icelandic nurses in smoking cessation counselling. J Clin Nurs 2008;17(10):1335-41.

3. Fernandez ML, Sanchez M. Evolución de la prevalencia del tabaquismo entre las médicas y las enfermeras de la Comunidad de Madrid. Gac Sanit. 2003;17(1):5-10.

4. Merighi MA, Jesus MC, Domingos SR, Oliveira DM, Baptista PC. Being a nursing teacher, woman and mother: showing the experience in the light of social phenomenology. Rev Latino-Am Enfermagem. 2011;19(1):164-70.

5. Lindseth A, Norberg A. A phenomenological hermeneutical method for researching lived experience. Scand J Car Sci. 2004;18(2):145-53.

6. Amezcua M, Gálvez A. Los Modos de Análisis en Investigación Cualitativa en Salud: Perspectiva Crítica y Reflexiones en Voz Alta. Rev Esp Salud Publica. 2002;76(5):423-36.

7. Hyland A, Rezaishiraz $H$, Bauer J, Giovino GA, Cummings KM. Characteristics of low-level smokers. Nicotine Tob Res. 2005;7(3):461-8.

8. McKenna $H$, Slater $P$, McCance $T$, Bunting B, Spiers A, McElwee G. Qualified nurses' smoking prevalence: their reasons for smoking and desire to quit. J Adv Nurs. 2001;35(5):769-75.

9. Bialous SA, Sarna L, Wevers ME, Froelicher ES, Danao L. Nurses' Perspectives of Smoking Initiation, Addiction, and Cessation. Nurs Res. 2004;53(6):387-95.

10. Sarna L, Lillington L. Tobacco: an emerging topic in nursing research. Nurs Res. 2002;51(4):245-53.

11. Wevers M, Kidd K, Armbruster D, Sarna L. Tobacco dependence curricula in U.S. baccalaureate and graduate nursing education. Nur Outlook. 2004;52(2):95-101.

12. Larabie LC. To what extent do smokers plan quit attempts? Tob Cont. 2005;14(6):425-8.
13. Schultz ASH, Hossain S, Johnson J. Modeling influences on acute care nurses' engagement in tobacco use reduction. Res Nurs Health. 2009;32(6):621-33.

14. Raherison C, Marjary A, Valpromy B, Prevot S, Fossoux H, Taytard A. Evaluation of Smoking Cessation Success in Adults. Resp Med. 2005;99(10):1303-10.

15. Palma S, Pérez-Iglesias $R$, Pardo-Crespo $R$, Llorca J, Mariscal M, Delgado-Rodríguez M. Smoking among pregnant women in Cantabria (Spain): trend and determinants of smoking cessation. BMC Pub Health 2007;7:65.

16. Grangé G, Vayssiere C, Borgne A, Ouazama A, L'Huillier J, Valensi $P$, et al. Description of tobacco addiction in pregnant women. Eur J Obst Gynecol Reprod Biol. 2005;120(2):146-51.

17. Röske K, Hannover W, Grempler J, Thyrian JR, Rumpf $\mathrm{HJ}$, John $U$, et al. Post-partum intention to resume smoking. Health Educ Res. 2006;21(3):386-92.

18. McKenna $H$, Slater $P$, McCance $T$, Bunting $B$, Spiers $A$, McElwee $G$. The role of stress, peer influence and education levels on the smoking behaviour nurses. Int J Nurs Stud. 2003;40(4):359-66.

19. Bloor RN, Mesón L, Crome IB. The effects of a nonsmoking policy on nursing staff smoking behaviour and attitudes in psychiatric hospital. J Psychiatr Ment Health Nurs. 2006;13(2):188-96.

20. Slater P, McElwee G, Fleming P, McKenna H. Nurses' smoking behaviour related to cessation practice. Nurs Tim. 2006;102(19):32-7.

21. Lancaster T, Stead LF. Self-help interventions for smoking cessation. Cochrane Database of Systematic Reviews 2005;4. doi. 10.1002/14651858.CD001118.pub2 22. Radsma J, Bottorff JL. Counteracting ambivalence: Nurses who smoke and their health promotion role with patiens who smoke. Res Nurs Health. 2009;32(4):443-52. 23. Katotomichelakis M, Balatsouras D, Tripsianis G, Davris S, Maroudias N, Danielides V, et al. The effect of smoking on the olfactory function. Rhinology. 2007;45(4):273-80.

24. Young C, Kornegay K. Understanding Why Health Care Professionals Continue to Smoke. J Addict Nus. 2004;15(1):31-5.

25. Andrews JO, Felton G, Wewers ME, Waller J, Tingen $M$. The effect of a multi-component smoking cessation intervention in African American women residing in public housing. Res Nurs Health. 2007;30(1):45-60.

Received: Oct. $19^{\text {th }} 2010$ Accepted: Oct. 26 th 2011 